\title{
The Role of Higher Education in Improving Micro, Small, and Medium Enterprises' Performance; A Case Study: Untar untuk UMKM
}

\author{
Agustinus Purna Irawan ${ }^{1,2 *}$ Hetty Karunia Tunjungsari ${ }^{1,3}$ \\ Paula Tjatoerwidya Anggarina ${ }^{3}$ Nicholas Rijako $^{4}$
}

\author{
${ }^{1}$ Master of Management, Universitas Tarumanagara, Jakarta, Indonesia \\ ${ }^{2}$ Faculty of Engineering, Universitas Tarumanagara, Jakarta, Indonesia \\ ${ }^{3}$ Faculty of Economics and Business, Universitas Tarumanagara, Jakarta, Indonesia \\ ${ }^{4}$ Faculty of Communication, Universitas Tarumanagara, Jakarta, Indonesia \\ *Corresponding author.Email: agustinus@untar.ac.id
}

\begin{abstract}
MSMEs (Usaha Mikro Kecil Menengah, or UMKM) are one of the important economic drivers in Indonesia. MSMEs can survive an economic crisis and can still run businesses with small capital. However, it takes effort to continue to develop the capacity of MSMEs in carrying out their business, so that they can grow into bigger businesses with good profits. One of the efforts made in fostering MSMEs is carried out by facilitating the promotion of MSMEs products using official social media belonging to Universitas Tarumanagara (Untar), so that it is increasingly known by consumers. This study aims to evaluate the Untar for MSMEs that has been launched for several month. The research methodology was conducted by observing the public and consumer responses to MSMEs products that were promoted through the official social media of Universitas Tarumanagara. The product display design has been made so well that it is interesting to look at. The results showed that the use of official social media from a credible higher education institution such as Universitas Tarumanagara received a positive response from the public and consumers seen from the number of visitors and those who gave likes to the product being promoted. Positive responses can also be observed from comments given by visitors to the products being promoted. The results of this study will become a reference in the development of further product promotion programs.
\end{abstract}

Keywords: MSMEs, social media, product promotion

\section{INTRODUCTION}

Micro, Small and Medium Enterprises (MSMEs) or Usaha Mikro Kecil Menengah (UMKM) are businesses that are carried out individually, household businesses, or carried out by business entities with small capital, limited labour, and small turnover. MSMEs are trading businesses that are managed by business entities or individuals who refer to productive economic enterprises in accordance with the criteria stipulated by Law Number 20 of 2008. MSMEs are one of the Indonesian economic forces that can survive various economic conditions. In the Indonesian economic system, MSMEs are the business groups that have the largest number. In addition, this group has proven to be resistant to various kinds of shocks to the economic crisis. Some Indonesians have realized that having a small and medium-sized business is very promising. In general, MSMEs development can be carried out using the following model (Figure 1). [1-5].

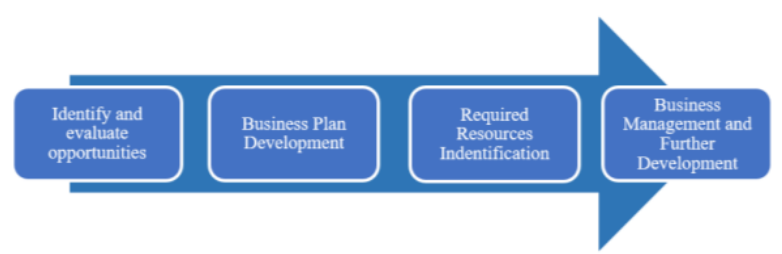

Figure 1. Flowchart of MSMEs development

One of the main advantages of MSMEs is the ease in adopting innovations in business, especially in the field of technology. This is due to easy bureaucracy, flexible systems, easy management of employees due to small numbers, and the flexibility to adapt the business to dynamic market conditions. However, success in developing MSMEs requires the right steps and strategies. If the strategy that is implemented is not quite right, there is a possibility that you will experience a loss. If MSMEs can carry out activities well and in accordance with measurable steps, this can increase the benefits of MSMEs (Figure 1) [6-1]. 
Several efforts to improve the performance of MSMEs can be undertaken independently and can be done in collaboration with partners. For example, improving the quality of products and services to consumers can be carried out independently or in collaboration. Likewise, the use of information technology to advertise products, market products, reach a wider market, and make various service innovations can be done in collaboration. All of this is intended to provide good service to all stakeholders, potential customers, and loyal customers [10-14]. One of the implementations of information technology that is currently trending is the use of social media to market products produced by MSMEs. Marketing models that are in accordance with consumer needs and can be accessed easily, both for viewing products, selecting products, making purchases and payments, as well as good product delivery, are very popular with customers. Digital marketing is one of the keys to success in selling MSME products because most people today have used the internet and social media for their daily activities. Online shopping is one of the new habits, especially during the COVID-19 pandemic. Therefore, MSMEs must be able to adapt to consumer desires, namely trust, convenience, quality of products and services as well as a variety of attractive sales programs [10-14].

The problem that may exist is that not all MSMEs are able to create, use and utilize social media and digital media to introduce and market their products. Likewise, the ability to use social media to reach potential consumers differs from one UMKM to another. Therefore, it needs to be facilitated is that MSMEs can use social media effectively and are trusted by consumers who need them. Related to this, Universitas Tarumanagara as one of the universities that has advantages and values in entrepreneurship, tries to carry out community service activities in the form of programs to promote MSMEs to potential consumers and collaboration partners. The activity was named: Untar untuk UMKM. This activity is in the form of using Untar's official social media to promote various UMKM products that want to be introduced to the public. This paper discusses the Untar program for MSMEs and how it impacts the development of MSMEs involved in this program and its impact on Untar itself as a university that develops entrepreneurship for students and lecturers, as well as the wider community.

\section{METHOD}

The MSMEs empowerment program is a program that is really needed by the community, especially MSMEs players who are experiencing problems due to the impact of the COVID-19 pandemic. Untar untuk UMKM is an effort to help MSMEs continue to run their business despite experiencing various obstacles. This paper discusses how the implementation of Untar untuk UMKM can be carried out properly. The discussion was carried out using the descriptive analysis method of the implementation of the Untar untuk UMKM. The discussion was also accompanied by case examples of several products promoted through the
Untar untuk UMKM. The implementation of activities follows the following flow Figure 2:

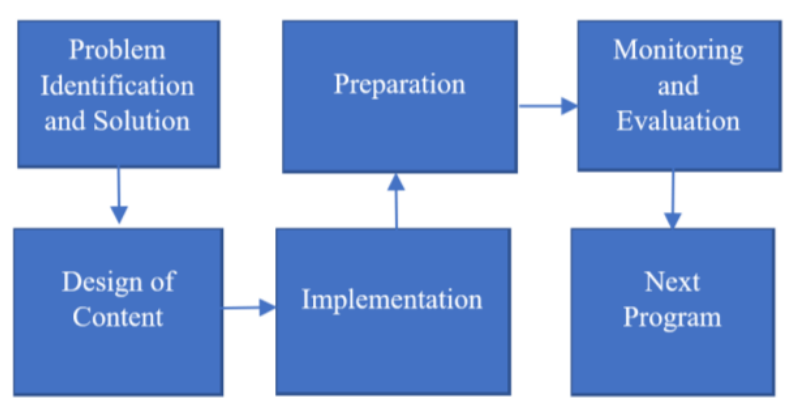

Figure 2. Flowchart of Untar untuk UMKM program

\section{RESULTS AND DISCUSSIONS}

Untar untuk UMKM is one of the programs implemented by Untar, especially the Untar Public Relations Team to help MSMEs in promoting their products. This activity is a community service activity carried out by Untar for free. MSMEs are invited to promote their products using official social media owned by Untar and managed by Untar's Public Relations. The Untar Public Relations team helps with the preparation, implementation, and evaluation of this promotional program. MSMEs were facilitated to promote their products for several days on Untar's social media, where content design was carried out by the Untar design team (Figure 3).

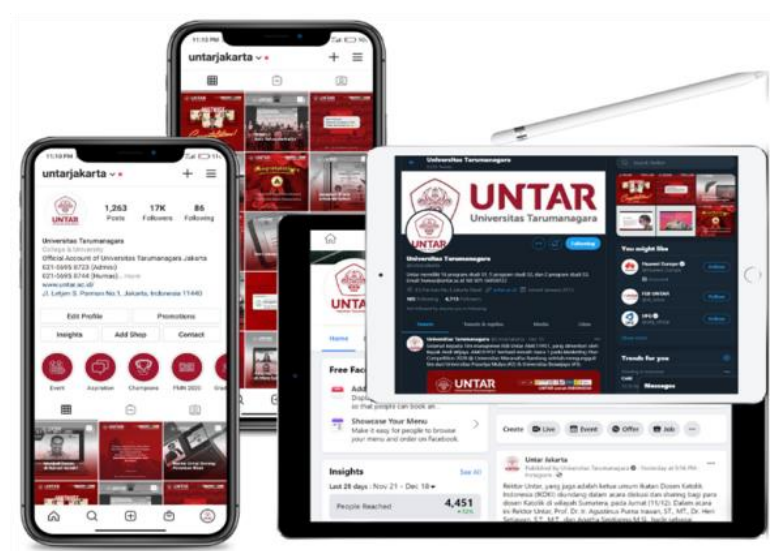

Figure 3. Untar untuk UMKM through Untar's official social media

The Untar untuk UMKM is open to the public, but at the beginning of the program it was aimed at facilitating students and lecturers who already have businesses in the form of MSMEs. Registration is carried out openly with announcements made on the Untar website and Untar social media. Each UMKM is given promotion time for 5 consecutive days and the progress of this promotion process is monitored, without being given daily intervention. 

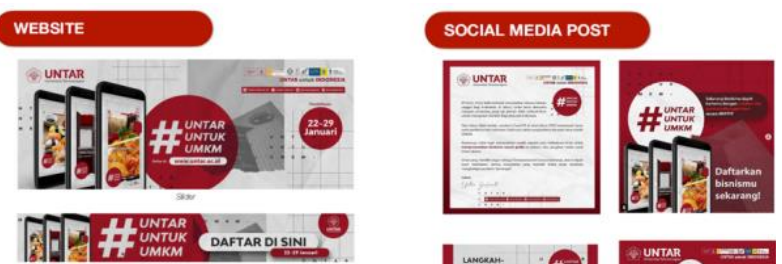

Figure 4. Display of Untar untuk UMKM on social media

Here are some examples of products promoted through Untar's social media for 5 consecutive days, with the number of visitors who saw the product:

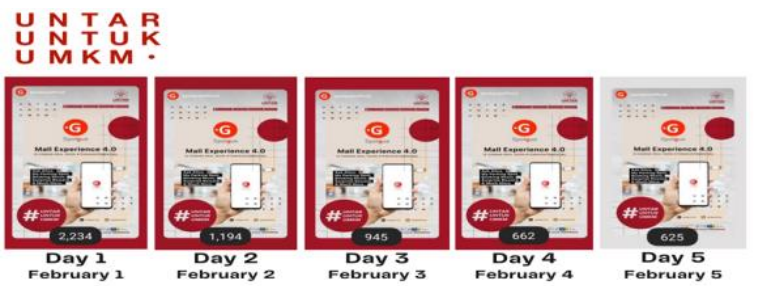

Figure 5. Reservation application for mall visitors

The reservation application for mall visitors is a one stop solution for your mall 4.0 experience. Since being posted on Untar's social media in Untar untuk UMKM program, the total number of visitors in 5 days is 5660 visitors.

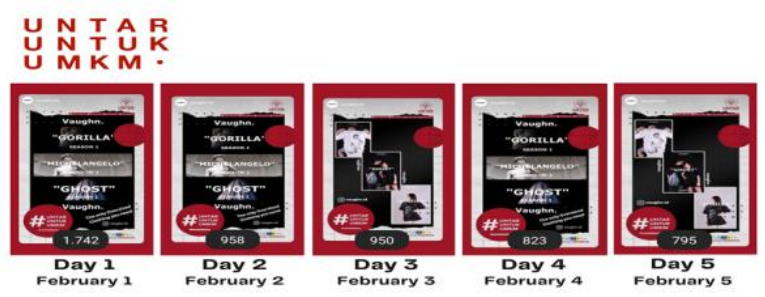

Figure 6. Fashion products promotion

Fashion products promoted through the Untar untuk $U M K M$ managed to get a total of 5268 visitors in 5 days.

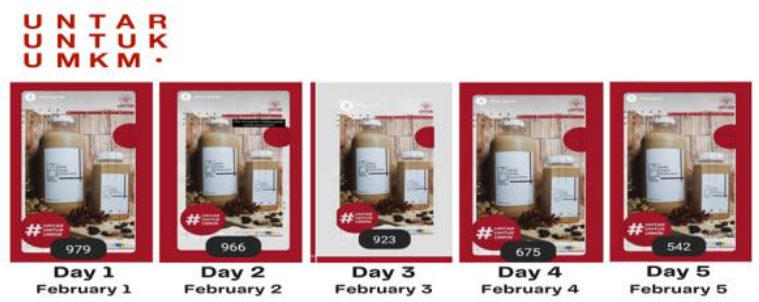

Figure 7. Promotion of beverage products

Beverage products promoted through the Untar untuk UMKM managed to get a total of 4085 visitors in 5 days. Of the 3 products that have been promoted through Untar's social media for 5 days for each product, the average amount of visitors who see the product is over 500 visitors per day. The highest number of visitors on the first day when the product is shown to the public through social media, with the number of visitors for 5 days between 4000 5500 visitors. The large number of visitors in this short time shows that social media from institutions that are trusted by the public have a positive impact on product promotion carried out by MSMEs. The public gives a positive response to posts that are good and interesting to access. The increase in the number of visitors to this official social media has brought benefits both to MSMEs who promote their products for free to the public and to Untar who also get appreciation from the community for helping to promote UMKM products. Therefore, mutual collaboration between the two parties provides mutual benefits. This is of course in line with the basic principles of entrepreneurship, namely building strategic partnerships between all stakeholders, so that all benefit from collaboration.

In general, the development of MSMEs requires partnerships in various matters, including to compile a business plan; carry out product, business, and service innovations; use of social media for promotion, product sales process and access to a wider market; good financial planning; looking for collaboration partners, identifying competitors and their products and services [11-14]. The Untar untuk UMKM has facilitated MSMEs to get the opportunity to design product advertising displays, advertise products, and take advantage of Untar's social media to reach the market and expand access for interested partners. This is very important because the role of social media is crucial in introducing products to the market and showing the existence of the product to consumers and competitors [11-12]. The forms of promotion that are carried out are also varied and are more attractive to consumers. Likewise, the introduction of competitors can be done by observing the behaviors of people accessing social media, whether in the form of comments, likes or dislikes, sharing content, or just accessing it without carrying out meaningful activities. By understanding competitors more deeply, MSMEs can carry out various product and service innovations that are better than those made by competitors so that they can be an option for consumers to buy the products they produce. MSMEs that have distinguishing values, characteristics and other advantages seen by consumers will get a good response from consumers and can develop even more rapidly [1314].

Untar untuk UMKM has successfully assisted 127 participants with various products. During the program held on 22-29 January 2021, it has received 300 website taps per week, more than 70,000 story views, an increase in followers by more than 400, profile visits increase during the campaign period: approximately $50 \%$ or 5000-6000 accounts per week.

Some comments and input for the Untar untuk UMKM from participants were as follows: Untar for MSMEs could present a more tangible movement in the future, not just by reposting Instagram stories, but by introducing the product directly; It is also a good idea for Untar to hold businessrelated seminars that will help MSMEs in developing their business; participants also expressed hope that this activity will continue to be held and can be made a highlight on Instagram Stories; in the future, we can schedule one day for one category, because from their experience, sometimes 
people are lazy to see a very long Instagram story; they hope this activity can be carried out again in the near future.

\section{CONCLUSION}

The development of MSMEs requires a variety of support from all stakeholders, including the involvement of universities. Higher education institutions can help, training, development of social media content, product promotion, packaging design, website design, business plan design and various other assistance according to the needs of MSMEs. This synergy can be beneficial for both parties, where MSMEs can continue to grow and develop into increasingly quality businesses, on the other hand, universities can also implement the results of studies, research and development carried out in real business [1114]. Based on the results of the research that has been done, it can be concluded that the Untar untuk UMKM has been successful in helping MSMEs to be recognized by the public. The introduction of MSME products by credible institutions such as universities through official social media can increase public confidence in the products produced and offered by MSMEs. Public trust is marked by the number of accesses to social media content that has been posted, the number of likes in a short time on the product being promoted, and positive comments on the product. The introduction of this early stage can be continued by providing advanced services by MSMEs in collaboration with universities. Through this collaboration, it is hoped that the process of selling products from MSMEs can continue to increase along with the trust that has been obtained by MSMEs from the community of product users.

\section{REFERENCES}

[1] Metasari Kartika, Public Service and Micro-Small Enterprise Developments in Indonesia, Integrated Journal of Business and Economics, Vol. 3 No. 1, 2019, pp. 108-115.

[2] Muhammad Adi Adrian, Empowerment Strategies of Micro, Small, Medium Enterprises (MSMEs) To Improve Indonesia Export Performance, International Journal of Economics, Business and Accounting Research, Vol. 2, No. 4, 2018, pp. 50-60.

[3] Umiaty Hamzani, Dinarjad Achmad, Micro, Small and Medium Enterprises (MSMEs) Coaching Program, Journal of Business and Economics Review, Vol. 2 No. 3, 2017, pp 20-25.

[4] Yuli Rahmini Suci, Perkembangan UMKM (Usaha Mikro Kecil Dan Menengah) Di Indonesia, Jurnal Ilmiah Cano Ekonomos, Vol. 6 No. 1 Januari 2017, pp. 51-58
[5] Erlangga Budi Sanggrama, Rhaisya Setiawati Rachmat, Se Tin, Sebuah Solusi untuk Perkembangan UMKM di Indonesia, Jurnal Akuntansi, Vol. 12, No. 1, Mei 2020, pp. 146-158.

[6] Amin Dwi Ananda, Dwi Susilowati, Pengembangan Usaha Mikro Kecil Dan Menengah (UMKM) Berbasis Industri Kreatif Di Kota Malang, Jurnal Ilmu Ekonomi, Vol. 1 No. 1, 2017, pp. 120-142.

[7] Nadia Sigi Prameswari, Mohamad Suharto, Narsen Afatara, Developing E-Commerce for Micro Small Medium Enterprise (MSME) to Cope with Cultural Transformation of Online Shopping, Jurnal Dinamika Manajemen, Vol. 8, No. 2, 2017, pp. 188-198.

[8] Ernani Hadiyati, Kukuh Lukiyanto, The Effect of Entrepreneurial Marketing Dimensions on Micro, Small and Medium Enterprise Performance in Indonesia, International Journal of Scientific \& Technology Research, Vol. 8, No. 10, October 2019, pp. 106-112.

[9] Aulia Ratnadianti Suharjo, Idqan Fahmi, Sufrin Hannan, Digital Marketing Strategy of Small and Medium Enterprises for Snack in Bogor City, Jurnal Manajemen \& Agribisnis, Vol. 17, No. 1, March 2020, pp. 74-85.

[10] Mohamad Nur Utomo, Kajian Strategi Pengembangan Usaha Mikro Kecil Dan Menengah (UMKM) Di Kota Tarakan, Jurnal Organisasi dan Manajemen, Vol. 13, Nomor 2, September 2017, pp. 99118.

[11] Nikola Draskovic, The Marketing Role of Packaging: A Review, International Journal of Management Cases, Vol. 19, No. 3/4, 2017, pp. 315-323.

[12] K. R. Subramanian, Impact of Packaging in Self Service Marketing, International Journal of Scientific Progress and Research, Issue 93, Volume 33, Number 02, 2017, pp. 60-66.

[13] Ujjal Bhuyan, A Study on the Performance of Micro, Small and Medium Enterprises (Msmes) in India, Global Journal of Management and Business Research, Vol. 16 No. 9, 2016. pp 33-36.

[14] Susanne Schwarzl, Monika Grabowsk, Online marketing strategies: the future is here, Journal of International Studies, Vol. 8, No 2, 2015, pp. 187-196. 